\title{
人の一生と環境 家政学の立場から
}

\section{工藤由貴子}

\section{はじめに}

人間の営みは自然とともにあり、その影響を 受けながら暮らしをつくり、また働きかけるこ とで自然環境にも影響や変化を与えている。そ の相互作用のバランスが崩れ、地球の持続可能 性が危ういものになっている。人間が地球の回 復力を超えた負荷をかけた結果生じた「環境問 題」を克服し、持続可能な社会を取り戻そうと いう動きが高まっている。

そこでは、「持続可能性のある社会を構築する ために、環境に配慮した生活が求められる」と いわれる。それは、生活を営む主体の側からみ ると出発点が違う。持続可能な社会をつくるこ とを目的に、その手段として環境親和的な生活 をつくるべきということではない。持続可能な 社会の基盤には人間の豊かな生活の保障がなく てはならず、人間の生活に真の豊かさを回復す ることが、持続可能な社会を構築していくこと に他ならないという、人間のエンパワメントを 意味する。社会の近代化、経済活動の拡大によっ て、生活環境にも、労働環境にも人間性の阻害 が生じ、次第に私たちの生活は「自然」から遠く なっている。ここから、再び人間の自然を取り 戻し、人間らしく生きるためにはどのような生 活のあり方が問われるか、私たちに与えられた 再考の好機と位置づけられる。

このような考え方のもとに、現代社会におい
て人と環境との相互作用の調和性が阻害されて いるのはなぜか、ここから再び豊かな「環境と の相互作用」を取り戻すために何が求められる かを家政学の立場 ${ }^{12}$ から検討してみたい。

\section{「環境亡の相互作用」は} 人間の生涯発達、文化の土壤

人と環境との関わりについて考えるところか ら始めたい。私たちは、生きるために被服をま とい、食べ物を食べ、住まいをつくる。さらに、 より安全に、楽しく、おいしく、きれいにあり たい等の生活欲求をもって環境と関わり続ける。

人は、様々な要素からなる生活事象を、個々 人の生活価值に照らして、それぞれの生活・人 生の文脈に位置づけながら生活の総体をつくり 上げる「営み」を行う。そのダイナミックな営み が「人と環境との相互作用」である（図1）。家政 学は、この「人と環境との相互作用」を学問の中 心に抒いて、人間が自分自身の身体という自然 的・精神的環境、空気、水、土、日光等の自然 環境、経済、家庭生活、コミュニティなどの社 会的環境との相互作用をしながら生活欲求を充 足する過程を研究対象としている。

「人と環境との相互作用」の向かう先にあるの はマクロにみれば「生活の質の向上と人類の福 祉」、「個人・家族・地域にとって最適で持続可 能な暮らし」の実現であり、ミクロな視点では、 


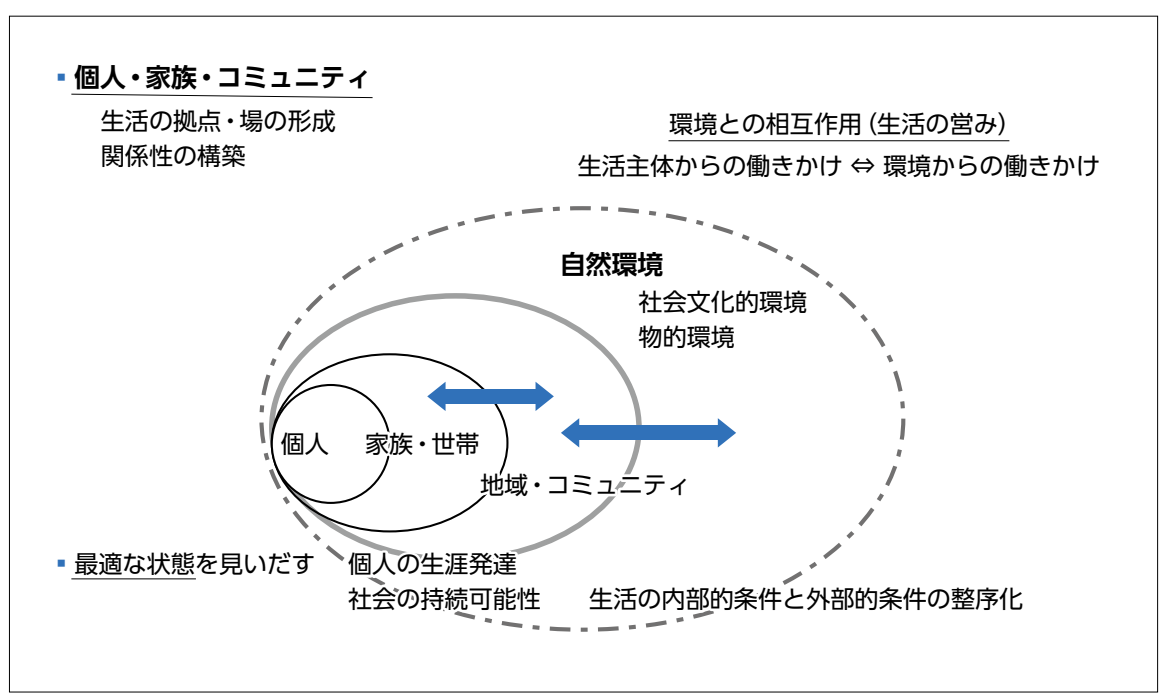

図1 生活の営み（人と環境との相互作用）

個々人それぞれの生涯発達の達成である注2。

人間の発達は、成長、発展、開発といった一 方向の変化（向上、拡大を意味するような）だけ ではなく、もっと多様で多方向に変化する（立 ち止まる、元に戻るという変化も含む)、より「自 然」なものである。そして「発達は新しい生活環 境に適応するために主体と環境との関係性を更 新していくプロセスである」注3 とされるように、 人間による主体的な周囲の環境との相互作用が 大前提である。私たちの生活の営みは、それを 囲む社会や文化等の環境の文脈に位置づけるこ とによって初めて発達として方向づけられる。

加齢、あるいは事故や病気によって機能障害 を起こしたとしてもその人がその事態を単に受 け身に体験するだけでなく、その変化に主体的 に向き合い、新しい環境との関係性を構築しな おすことができれば発達し続けることはできる し、反対に、子どもでも青年でも障がいをもた ない人でも、単なる環境の受け手に留まり、自
ら環境との相互作用をし ようとしなければ十分な 発達は望めないというこ とになる。このように人 間にとって、マクロにも ミクロにも環境との相互 作用は本質的なものであ り、できるだけ豊かな相 互作用を行えるような環 境が、自分のまわりに多 様なかたちで存在するこ とが不可欠になる。

さらに、そうした環境との相互作用は、人 間としてより豊かに生きるという判断のもとに 総合され続けることによって、日々の着る、食 べる、住むという行為は人間の「衣生活（衣文 化）」、「食生活（食文化）」、「住生活（住文化）」 という時間軸をもった生活の総体となり、生活 文化、ライフスタイルとして世代を超えて伝承 され、新しい創造の源ともなる。このように人 間と環境との相互作用は、ライフステージを通し た生涯発達の視点とライフサイクルのつながり、 過去一現在一未来という長期的な時間軸を含んで いる。そして、持続可能な社会は、このような生 活の営みの継続によって実現されるはずである。

\section{調和的な [環境と人との相互作用] を阻害するもの}

人間が豊かな生活をまっとうすれば、持続可 能な社会が築けるはずである。なぜなら、自然 
と人間の双方の調和を大切なこととして、多様 なもののバランスをとりながら、その場その場 で最適だと判断できる解決策を求めていく人間 にとって、それこそが必然だからである。

しかし、現実はそうなってはいない。現代社 会には環境との相互作用を通して実現されるは ずの人間の十全な発達を阻害する要因が多くみ られる。社会全体としても持続可能な方向に進 んでいるとはいえない状況にある。

例えば、人間にとって「自然」そのものである エイジング (老い) を例にとって考えてみよう。 今私たちを取り巻く社会は変化のスピードが速 くなり、物事を捉える時間軸も変化している。 長期にわたる時間軸で物事を考えることがすく なくなり、人は今という時間の中で動き、自分 の時間の価值を常に意識しながら人生を無䭾な く効率的に、合理的に管理しようとする傾向が 強まっている。

このような社会では、人間にとって自然な発 達であるはずの老いも「自然」でなくなってい て、多くの人は老いの過程を自分のペースに合 わせてじっくり味わうことも、まわりの人がそ こに注目することもしなくなっている。今とい う時間枠の中でできるだけ良い機能を発揮する ことが重視される社会においては、メンテナン スをしたり、立ち止まり、別の方法を試したり しながら歩んでいく自然な老いの過程は見えに くくなってしまう。

長い間をかけて住みこなしの知恵や技術を培 い、まわりの環境とかかわりながら自分にとっ て意味ある場所をつくり、その場所で最期まで
自分らしく住み続けたいという希望も、高齢者 の生活の質のためには、安全・安心な機能を備 えたバリアフリーの空間が最優先であるという 「科学的」な見解によって生活主体者から奪い去 られてしまう。断片的な時間、そして、誰にとっ ても同じ意味しかもたない空間で生きる人たち にとって、「自然な老い」を生涯かけて緩やかに ゆっくり生きるという権利（機会）が奪われてし まっている。

このような時間・空間で生きる人には老いも 病気もある日突然にやってくる。自然のサイク ルと遠く離れてしまった人間には、老いや病も 生活の営みの上で欠くことのできない自然であ ることを受け入れることは難しい。そこでは専 門家による治療の技術や効果が強調され、人間 の生活は部分ごとに分析され、治療の必要性に 基づいた画一的な対応が行われる。そこにはそ の人間のもっている価値や背景への配慮はなく、 長期にわたる時間を共有し、見守り、回復しょ うとする力を信じ応援するというような人間に とって本質的な関係性は生まれにくい。

\section{「科学の合理性」から 「人間の自然」への転換を}

ここから再び、人の生活と環境との相互作用 をバランス良いものに回復させるために、どの ような方向性が考えられるだろうか。家政学者 の岸本氏による、「生活の科学化」から「科学の 生活化」に一つの答えを見いだすことができる (図2)。 


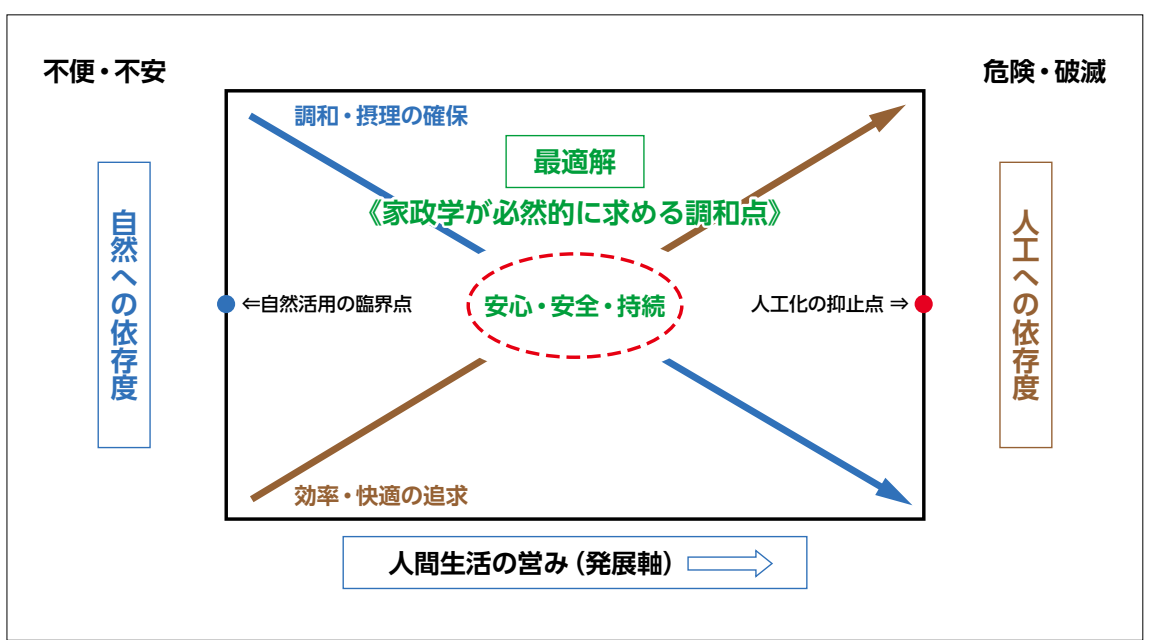

图2 生活と環境の相互作用 (自然環境の構成要因としての人の生き方)
あり方への巻き返し、す なわち、「人間の自然」の 回復を意味する。

コントロール不可能な 人間という自然を、まわ りの環境から切り離して、 できるだけ効率的に発達 させることが幸せである かのように語られてきた ことからの転換、まわり の環境から切り離された

科学技術の急速な進展に伴い、これまで人間 はそれを使って生活を発展させることを目指し てきた (生活の科学化)、しかしここからは、持 続可能な生活の視点から自然と人間の双方が調 和する最適解を求めていく、本来の人間の営み へと生活を回復させていくこと（科学の生活化） が求められる。

「学問」もまた、時代と共により細分化が進み、 生活の実態からかけ離れてしまっている。細分 化された分野の成果を、今一度、どのように受 け入れることが相応しいのか、それを人間生活 の視点から総合的に検証し、学問の成果を生活 に適切に還元できるような思考が求められてい る。そこでは、自然科学、社会科学という従来 の科学の枠組みを超えた専門の統合、科学的な 思考、文化的な思考を統合した人間的思考が不 可欠であるとされる注 4

それを生活の営みに立ち戻って考えてみれば、 固有の状況をもったトータルな人間として環境 との相互作用を行うことができるような生活の
抽象的な個人としてではなく、自分がその場に いて感じとる身体的経験、空気、雲囲気といっ た環境と呼応し、まわりの人やコミュニティを 大切に生きる具体的な人間でいられることへの 転換が必要である。

自然を取り戻した人間にとっては、衣食住の 暮らしも、欲しいものを手に入れ、消費し、要 らないものは捨てるといったものから、自分の 落ち着ける場所を築き、生き生きとした生活を 実感できる時間や場所をつくるための行為と変 化することができるだろう。着る、食べる、住 むといった日常の暮らしにおいて「どのようで ありたいか」という生活欲求の中に「人間の自 然」を取り戻すこと、私たちが、気持ち良い、 快適だという感覚に、環境と人間の生活との調 和を不可欠なものとして位置づけて、生活欲求 の充足過程のすべてにおける選択を、意識的に、 主体的に積み重ねていくことから、変えていく ことができるだろう。

人と人との関係性においても、自分にとって 
どれだけ役立つかという機能を重視し、必要な ものだけを取捨選択するような不自然な関わり 合いを、存在そのものの多様性を尊重し、全体 的かかわりをする場や関係性を取り戻すことか ら、人生の基盤をつくる人間関係形成が可能に なるはずである。そのことによって、社会の近 代化、産業の変化、経済や社会システムの肥大 化のなかで受動的に反応しがちだった生活は再 び自律的なものへと変わり、それが社会を変え ていくことにもつながっていくだろう。

\section{おわりに}

モンスーン気候区に住む私たちは、「五風十 雨」という諺をもつ。五日もすれば風が吹き、 十日もすれば雨が降る、自然に任せておけばな るようになるという言い伝えに、大きな自然の なかで見えないものに目を凝らし、その力に飲 み达まれることなく足元をふみしめ、巡る時を 生きる人間のすがたがみえる。

自然と対話をしながら、個人・家族・コミュ ニティの豊かな生活を求めて協働していく多様 な人たちが、人間が人間らしく生きるためにど のような時間、場所が確保されるべきかを問い、 草木の手入れをするように時間をかけてそれを 育んでいく環境との関わりの中で、資源を分か ち合い、持続可能なかたちで未来の世代にも美 しい地球を残す共生の道を実現していくのだろ う。
注

注1「家政学は、人間の基本的な生命維持の欲求と必要の充足 にかかわる家庭の生活を物心両面において向上させること を指向する学問である。人間が人間らしく生きてゆくには どうしたらよいかという原点に立ち戻って家庭の将来に 思いをはせる」、田辺義一『家政学総論』光生館、1971、 186-187。

注2 第22期日本学術会議健康・生活科学委員会 家政学分野の 参照基準検討分科会報告（2013）「家政学は、人間生活に おける人と環境との相互作用について、人的・物的両面か ら研究し、生活の質の向上と人類の福祉に貢献する実践的 総合科学である」。

International Federation for Home Economics（国際家政学 会 ) Position Statement (2008) "Home Economics in the 21st Century”「家政学は個人・家族・地域にとって最適で 持続可能な暮らしを実現する」ための人間科学（自然科 学、社会科学という科学の伝統的枠組みを超えた総合的な 学問）であり専門である」。

注3 城仁士「発達をとらえ直す」『地域リハビリテーション」 2009, 4(2), 182-183。

注 4 岸本幸臣「規範科学としての家政学の今日的使命」『家政 学原論研究』2006, 40,14-20。

\section{参考文献}

1 内山節『時間についての十二章』岩波書店、1993

2 岸本幸臣「生活するということ」『家政学のじかん』関西家 政学原論研究会、2011。

3 工藤由貴子「自然とコミュニティとケア」『自然との関わり を通じたケア』国際長寿センター、2000。

4 工藤由貴子「生活経営一一新しい価值・規範の創造へ」『暮 らしをつくりかえる生活経営力』朝倉書店、2010。

5 松村祥子「生活とは何か」『持続可能な社会をつくる生活経 営学』朝倉書店、2020。

6 中村桂子『科学者が人間であること』岩波新書、2013。 